\title{
A Rare Case of CML with Abnormally High TLC Count
}

Madeeha Subhan Waleed ${ }^{1 *}$, Waleed Sadiq ${ }^{2}$

${ }^{1}$ Graduate, Ayub Medical College, Pakistan.

${ }^{2}$ Resident Physician, Staten Island University Hospital, New York, NY, USA.

*Corresponding Author: Madeeha Subhan Waleed, Graduate, Ayub Medical College, Pakistan.

Received date: October 06, 2020; Accepted date: October 19, 2020; Published date: October 28, 2020

Citation: M S Waleed, W Sadiq. (2020) A Rare Case of CML with Abnormally High TLC Count. International Journal of Clinical Case Reports and Reviews. 4(1); DOI: 10.31579/2690-4861/074

Copyright: () 2020 Madeeha Subhan Waleed, This is an open-access article distributed under the terms of the Creative Commons Attribution License, which permits unrestricted use, distribution, and reproduction in any medium, provided the original author and source are credited.

\section{Abstract}

CML is a neoplastic transformation of the primitive hemopoietic stem cells.CML presents with increased TLC count and low lap score.Diagnosis is made using peripheral smear,flow cytometry or bone marrrow biopsy. The incidence of this disease has remained stable for the last decade. We present to you a young male with CML and abnormally high WBC count of 175 000/uL , low LAP score and anemia.Philadelphiahia chromosome (9:22 translocation) is positive.

Keywords: neoplastic transformation; hemopoietic stem cells; TLC; CML

\section{Introduction}

Chronic myelogenous (CML) or chronic granulocytic leukemia (CGL) is a malignancy of the white blood cells.it accounts for $15 \%$ of the adult leukemias.in severe cases.it has three phases i.e chronic, accelerated and the blast phase.Blast crisis is defined as the presence of $\geq 30 \%$ marrow blasts [1]. The translocation of 9,22 chromosome leads to a fusion protein bcr-abl tha is an active tyrosine kinase .chronic myeloid leukemia (CML) patients receive imatinib which is a tyrosine kinase inhibitors as first-line therapy achieve good cytogenetic and molecular responses [2,3]

\section{Case Presentation}

A 39 year old previously healthy male presented to the hospital with weightloss, left sided chest discomfort and tightness for two months. These symptoms started gradually. The pain was burning in character which didnot radiate anywhere. There were no aggravating factors.It was intially relieved by pain killers but then slowly it increased to the point where he decided to seek medical attention.There was no associated shortness of breath,sputum production,cough or hemoptysis.Moreover,he also complained of generalized fatigue,malaise low grade fever for 2 months.He lost about $7 \mathrm{kgs}$ during this period.On review of system there was no headache,visual changes, vomiting, urinary or bowel problems. Regarding his social history he is an electrician ,non-alcoholic and nonsmoker but eats naswar(sun dried tobacco leaves).On examination, he had no edema,pallor,petechia,pallor,clubbing or lymphadenopathy.Cardiovascular and respiratory exam was unremarkable.On abdominal exam,there was no tenderness. The spleen was palpable two finger breadth below the costal margin and the bowel sounds were hypoactive.It was decided to admit him and appropriate laboratory investigations were ordered.The patient was started on ceftriaxone and vancomycin since he was febrile.
Laboratory Workup: Complete blood picture:

\begin{tabular}{|l|l|}
\hline Hemoglobin & $9.3 \mathrm{~g} / \mathrm{dl}$ \\
\hline Tlc count & $170750 / \mathrm{mm} 3$ \\
\hline Rbc count & $2.98 \mathrm{mil} / \mathrm{mm} 3$ \\
\hline Platlet & $279,000 / \mathrm{mm} 3$ \\
\hline metamyelocytes & $20 \%$ \\
\hline myelocyts & $18 \%$ \\
\hline blasts & $5 \%$ \\
\hline
\end{tabular}

\section{Peripheral smear:}

There was marked leuckocytosis with bimodal peak of neutrophils and immature granulocytes.Anemia with rbc morphology showing anisocytosis ,hypochromia,pokilocytosis with pencil cells. Platelets were adequate.Peripheral film was suggestive of chronic myeloid Leukemia. ESR: 76/1st hour.

Blood metabolic profile:

\section{Blood metabolic profile:}

\begin{tabular}{|l|l|}
\hline Total bilirubin & $0.7 \mathrm{mg} / \mathrm{dl}$ \\
\hline Cknac & $50 \mathrm{U} / \mathrm{l}$ \\
\hline calcium & $10.8 \mathrm{mg} / \mathrm{dl}$ \\
\hline ASAT & $23 \mathrm{U} / \mathrm{l}$ \\
\hline ALAT & $19 \mathrm{U} / \mathrm{l}$ \\
\hline Alkaline phosphatase & $433 \mathrm{U} / \mathrm{l}$ \\
\hline Creatnine & $0.9 \mathrm{mg} / \mathrm{dl}$ \\
\hline Urea & $24 \mathrm{mg} / \mathrm{dl}$ \\
\hline sodium & $140 \mathrm{mmol} / \mathrm{l}$ \\
\hline potassium & $3.2 \mathrm{mmol} / \mathrm{l}$ \\
\hline
\end{tabular}




\section{Chest Xray: Normal study}

Philidalpheia chromosome was positive.

Urine R/E: Normal

LAP score: 02

Diagnosis was confirmed with flow cytometry.

\section{Discussion}

CML occurs in $7 \%$ to $15 \%$ of all leukemias in adults with approximately 1 to 1.5 cases per 100,000 population $[4,5]$. Asymptomatic cases of CML have increased from $15 \%$ to about $40 \%$ of all cases.A European study published in 2007 estimates the CML incidence to be 1-2 cases per 100,000 people every year [6].The activity of leukocyte alkaline phosphatase is reduced in nearly all patients at diagnosis [7].According to Medscape total WBC count $20,000-60,000$ cells/ $\mu \mathrm{L}$ in CML with mildly increased basophils and eosinophils while in our patient it was $175,000 / \mathrm{uL}$. The most common feature of CML is an increased WBC count, usually above $25,000 / \mu \mathrm{L}$ [8]. Some patients have wide cyclic variations in their WBC count, with peak counts every few days or separated by up to 70 days [9]. The WBC differential usually shows granulocytes in all stages of maturation, from blasts to mature granulocytes that look morphologically normal.Most patients have mild anemia on diagnosis.

\section{Conclusions}

Patient suffering from CML may have a subtle presentation.Blood work up will often lead to diagnosis of CML. They may present with TLC count greater than 100,000 which is usually a feature of Acute Leukemia.Extreme leukoctytosis can cause leukostasis which itself contribute to additional complications.Imitanib should be started in bcrabl positive patients to bring wbc count in the normal range and the response should be monitored as some patients might require leukaphereis.As CML is one of the four main types of leukemia that affects and accounts for $15 \%$ of all the leukemias worldwide approximately,so proper workup and therapy should be started immediately to decrese mortality and morbidty.

\section{References}

1. Silver RT. (1968) Characteristics of the terminal phase of chronic granulocytic leukemia. Blood. 445-459.

2. O'Brien SG, Guilhot F, Larson RA et al. (2003) Imatinib compared with interferon and low-dose cytarabine for newly diagnosed chronic-phase chronic myeloid leukemia. N Engl J Med. 348, 994-1004.

3. Hughes TP, Kaeda J, Branford S et al. (2003) Frequency of major molecular responses to imatinib or interferon alfa plus cytarabine in newly diagnosed chronic myeloid leukemia. $\mathrm{N}$ Engl J Med. 349, 1423-1432.

4. Brincker H. (1982) Population-based age- and sex-specific incidence rates in the 4 main types of leukaemia. Scand J Haematol. 29:241-249.

5. Call TG, Noel P, Habermann TM. (1994) Mayo Clin Proc. 69:315-322.

6. M, Rohrbacher and J, Hasford. (2009) Epidemiology of chronic myeloid leukaemia (CML). Advances in Biology and Therapy of Chronic Myeloid Leukaemia. 22:295-302.

7. Rosner F, Schreiber ZR, Parise F. (1972) Leukocyte alkaline phosphatase. Arch Intern Med. 130:892-894.

8. Canellos GP. (1976) Chronic granulocytic leukemia. Med Clin North Am. 60:1001-1018.

9. Inbal A, Akstein E, Barak I et al. (1983) Cyclic leukocytosis and long survival in chronic myeloid leukemia. Acta Haematol. 1983, 69:353-357. 